\title{
Relation between the sedimentary organic record and the climatic oscilations in the Holocene attested by palynofacies and organic geochemical analyses from a pond of altitude in southern Brazil
}

\author{
GABRIELLI T. GADENS-MARCON ${ }^{1,2}$, JOÃO G. MENDONÇA-FILHO ${ }^{3}$, \\ MARGOT GUERRA-SOMMER ${ }^{1}$, MARCELO A. CARVALHO ${ }^{4}$, \\ ETIENE F. PIRES ${ }^{5}$ AND LÉO A. HARTMANN ${ }^{1}$ \\ ${ }^{1}$ Universidade Federal do Rio Grande do Sul, Instituto de Geociências, \\ Departamento de Paleontologia e Estratigrafia, Prédio 43127, Sala 201, \\ Avenida Bento Gonçalves, 9500, 91501-970 Porto Alegre, RS, Brasil \\ ${ }^{2}$ Universidade Estadual do Rio Grande do Sul, \\ Avenida Bento Gonçalves, 8855, 91540-000 Porto Alegre, RS, Brasil \\ ${ }^{3}$ Universidade Federal do Rio de Janeiro, Departamento de Geologia, \\ Instituto de Geociências, Centro de Ciências Matemáticas e da Natureza, \\ Avenida Athos da Silveira Ramos, 274, Bloco J1, Sala 20, \\ Ilha do Fundão, 21941-916 Rio de Janeiro, RJ, Brasil \\ ${ }^{4}$ Museu Nacional, Universidade Federal do Rio de Janeiro, Quinta da Boa Vista, \\ Bairro São Cristóvão, 22040-040 Rio de Janeiro, RJ, Brasil \\ ${ }^{5}$ Universidade Federal do Tocantins, Campus de Porto Nacional, Laboratório de Paleobiologia, \\ Rua 07, Quadra 15, Bairro Jardim dos Ipês, 77500-000 Porto Nacional, TO, Brasil
}

Manuscript received on July 1, 2013; accepted for publication on November 26, 2013

\begin{abstract}
This paper presents the quantitative and qualitative results obtained from palynofacies and geochemistry analyses carried out on a core covering approximately 8000 years of sedimentation of a pond of altitude located at the mining district of Ametista do Sul, southernmost Brazil. The main objective of this paper is to consider the paleoclimatic and paleoenvironmental significance of these analyses. The hydrological isolation renders this pond climatically sensitive to variations in pluviometric regime and this enabled infer rainfall events during the early Holocene, which was responsible for the beginning of the processes of water accumulation in the gossan and the sedimentation of the pond. Changes in the pattern of moisture over the time become the drier environment, resulting in the intermittent pattern of water depth that currently exists at the site. The fluctuations in water depth are inferred from the frequency of Botryococcus and other algae, which tend to decrease progressively toward the top where the autochthonous elements are replaced by parautochthonous and allochthonous elements. Pseudoschizaea, in turn, appears to act as a biological marker of these transitional intervals. The present results are of great importance for understanding the extent of climate change and its environmental impacts at regional and global levels.
\end{abstract}

Key words: continental environment, pond, organic matter, palynofacies analysis, total organic carbon, total sulfur.

Correspondence to: Gabrielli Teresa Gadens Marcon

E-mail: gabigadens@yahoo.com.br 


\section{INTRODUCTION}

Lakes can be viewed as dynamic response systems that integrate environmental, climatic and tectonic forces into a continuous and high-resolution archive of local and regional changes (Gierlowski-Kordesch and Kelts 2000).

Organic matter $(\mathrm{OM})$ constitutes an important fraction of the lake sediments, providing important information for the interpretation of lacustrine paleo-environments, the history of climate change and the effects of regional and local anthropogenic actions. However, lake systems are diverse, and the sources and alterations in $\mathrm{OM}$ are geographically and temporally variable, covering a broad spectrum from predominantly algal in certain locations to largely land derived in others (Meyers and LallierVerges 1999). Consequently, OM accumulation and preservation in lakes with different geo-morphological and climatic regimes is directly influenced by local, regional and global climatic conditions.

Meaningful reconstructions of the paleoenvironmental and climatic history of lacustrine deposits have been achieved in the last twenty years via palynofacies analyses combined with other methods of investigation of the tropical and temperate sedimentary records in different regions of the world (Siffedine et al. 1994, 1995, 1996, 1998, Noel et al. 2001). In the Holocene Brazilian lacustrine sedimentary records, organic matter analyses were obtained from multiple parameters (total organic carbon, Rock Eval pyrolisis, C/N determination, organic petrography, radiocarbon dating) and have proven their utility for paleo-climatic and paleoenvironmental reconstructions (e.g., Sifedine et al. 2001, 2003, Ledru et al. 2001, 2002, Tturcq et al. 2002, Jacob et al. 2004, 2005, Boussafir et al. 2012).

Many of the interpretive models available in the scientific literature that address organic geochemical and palynofacies analyses were designed for use in marine and epicontinental sections because these studies were focused towards the exploration of hydrocarbon source rocks. Notably because of it, studies based on palynofacies and organic geochemistry analyses of OM have been widely applied in the investigation of Brazilian deposits of marine origin and epicontinental samples from Paleozoic (Mendonça-Filho 1999), Mezosoic (Carvalho et al. 2006a, b, Iemini et al. 2007) and Cenozoic rocks (Del Papa et al. 2002, Menezes and Mendonça-Filho 2004, Meyer et al. 2005, 2006, Chagas et al. 2009, Mendonça Filho et al. 2010a). In contrast, only a few papers have added to the knowledge of environmental changes in the continental areas through palynofacies analyses on peatlands (Medeanic and Silva 2010) or inland lacustrine deposits (Meyer et al. 2010, Silva et al. 2010) of Quaternary.

However, the study of Sebag et al. (2006) provides evidence that the palynofacies method offers a valuable contribution for connecting particulate OM to the depositional environments in Holocene deposits; this work also includes a review of the main approaches performed for the POM characterization from Quaternary deposits in recent terrestrial environments and is based on applied examples in surface deposits, soil profiles, wetlands, lacustrine ecosystems and within catchments.

The present study was carried out using palynofacies and organic geochemical analyses of a particular type of inland ephemeral pond, located on a hilltop, in the sub-tropical climatic belt in the southernmost part of Brazil. This type of pond dries up periodically and is filled primarily by precipitation. The hydrological isolation, possibly, renders this pond highly sensitive to climatic change because the water entering the system is subsidized exclusively by rainfall. These peculiar characteristics can provide quite accurate data about the pluviometric regime in that region over the Holocene and also allow a correlation with the global scale paleoclimate records.

The Southern Hemisphere climate change during theHolocene periodhavereceived considerableresearch attention in recent years, particularly with respect to the timing and correlation of climate events in the history of the northern hemisphere climate (Markgraf 1998). The Bond events (Bond et al. 1997, 2001), registered 
in the North Atlantic sediment cores have been related to precipitation with anomalies over regions affected by the monsoons in Oman (Fleitmann et al. 2003), Asia (Wang et al. 2005), South America (Haug et al. 2001, Baker et al. 2001, 2005) and Brazil (Cruz et al. 2005). Recently, Stríkes et al. (2011) observed that the records of the Southeastern Brazilian speleothems are synchronous with those obtained by Bond et al. (1997), evidencing strong events of increased precipitation centered at 9.2, 8.2 , 7.4 , 7.0, 6.6, 5.2, 4.0, 3.2, 2.7, 2.3, 2.2, and 1.9 kyr BP. Based on Quaternary sediments from a paleo-lagoon in Southeastern Brazil, Sallum et al. (2012) found a relationship with the $8.2 \mathrm{ka}$ event, which is also associated with the Bond events.

The absence of any crystalline deposits that could potentially generate speleothems in southern Brazil (state of Rio Grande do Sul) have impeded, until the moment, correlations of this kind with the Bond events. Thus, the climatic inferences for the southern Brazil has been established mainly by palynological records (Behling et al. 2004, 2005) that led to infer cyclical climatic oscillations for the Holocene. Medeanic and Silva (2010) performed a palynofacies analyses somewhat different methodology of this work. The study conducted by these authors, in a Quaternary peatland of southern Brazil, allowed to infer humid-dry oscillations from the percentage ratio between fungal spores and freshwater algal. However, such paleoclimate data obtained for southern Brazil have not been correlated with the Bond events.

Considering that lacustrine sediments can potentially contain continental paleo-records of global change that match those records available from the oceans or ice cores, a pioneering investigation of the paleo-environmental and paleo-climate evolution in the highlands of southern Brazil based on palynofacies and organic geochemical analyses was established.

In light of the above considerations, the main goals of the present study are: (i) to present the quantitative and qualitative results obtained from palynofacies and organic geochemistry analyses carried out on a sedimentary profile covering approximately 8000 years of sedimentation from a Holocene subtropical ephemeral pool; (ii) to consider the paleoclimatic and paleoenvironmental significance of the palynofacies analyses; (III) to investigate whether the hydrologic isolation of the pond makes the sedimentary organic record climatically sensitive to variations in pluviometric regime; (iv) to assess the extent of the climatic changes reflected by change in the organic matter record.

GEOLOGICAL BACKGROUND AND SITE DESCRIPTION

The present investigation was focused on the sedimentary record recovered from a Holocene inland altitude pond, which was observed to dry up periodically. The pond is located on a hilltop in the Ametista do Sul mining district in the State of Rio Grande do Sul in southern Brazil at an altitude of 500 mabove sea level (Fig. 1)(Hartmann 2008). Favorable aspects for the study include: (i) the hydrodynamics of the alluvial plains, which have a strong influence upon adjacent systems appear to have no influence in this area because the pond is isolated on a hilltop; (ii) the pond area is partly filled with sediments and (iii) the pond is directly subordinated to the regional pluviometric regime. According to Hartmann (2008), pools displaying similar morphologies are common in the studied area and might have originated from the claying of Cretaceous basalts by the action of hydrothermal fluids.

The local present-day climate consists of a subtropical climatic zone framed by the climatic type Cfa (subtropical-humid) of Köppen (1948), and the modern-day vegetation is dominated by semideciduous forests that belong to the Mata Atlantica. The bedrocks (basalts and rhyodacites) from the Cretaceous (135 Ma) Paraná volcanic province are included in the Serra Geral Group. These units cover an area of $917.000 \mathrm{~km}^{2}$ in southeastern South America. The volcanic province is located near the top of the sedimentary Paraná Basin, which contains the notably large Guarani aquifer situated directly below the lavas (Araújo et al. 1999). This aquifer consists mostly of sandstones of the Botucatu 
and Guará Formations (Scherer 2000). According to Hartmann et al. (2010), heating by volcanism provided a widespread and nearly infinite volume of hot water and vapor for basalt alteration and the related processes of cavity formation and filling.

The formation of amethyst geodes is explained by Hartmann (2008), Duarte et al. (2009) and Rosenstengel and Hartmann (2012) via the ascent of hot water and its vapor and the consequent alteration of the overlying basalts. This process also led to the formation of ponds identified as "gossans" (Hartmann 2008), which have been considered as important guides for mineral prospecting (Pertille et al. 2013) due to their consistent relationship to the underground amethyst mines. Pools showing similar morphology are common in the studied area, and according to Hartmann et al. (2010, 2012), have the same origin; in other words, the formation of gossans is due to supergenic processes in which weathering is superimposed on the hydrothermal systems, constituting an anomaly coincident with the mineralization of amethyst geodes. According to Hartmann et al. (2012), the formation of smectite in the altered and mineralized rocks leads to the concentration of similar minerals in the overlying soil and a decrease in mass, and consequently, to the longterm residence of water in the depression or pond.
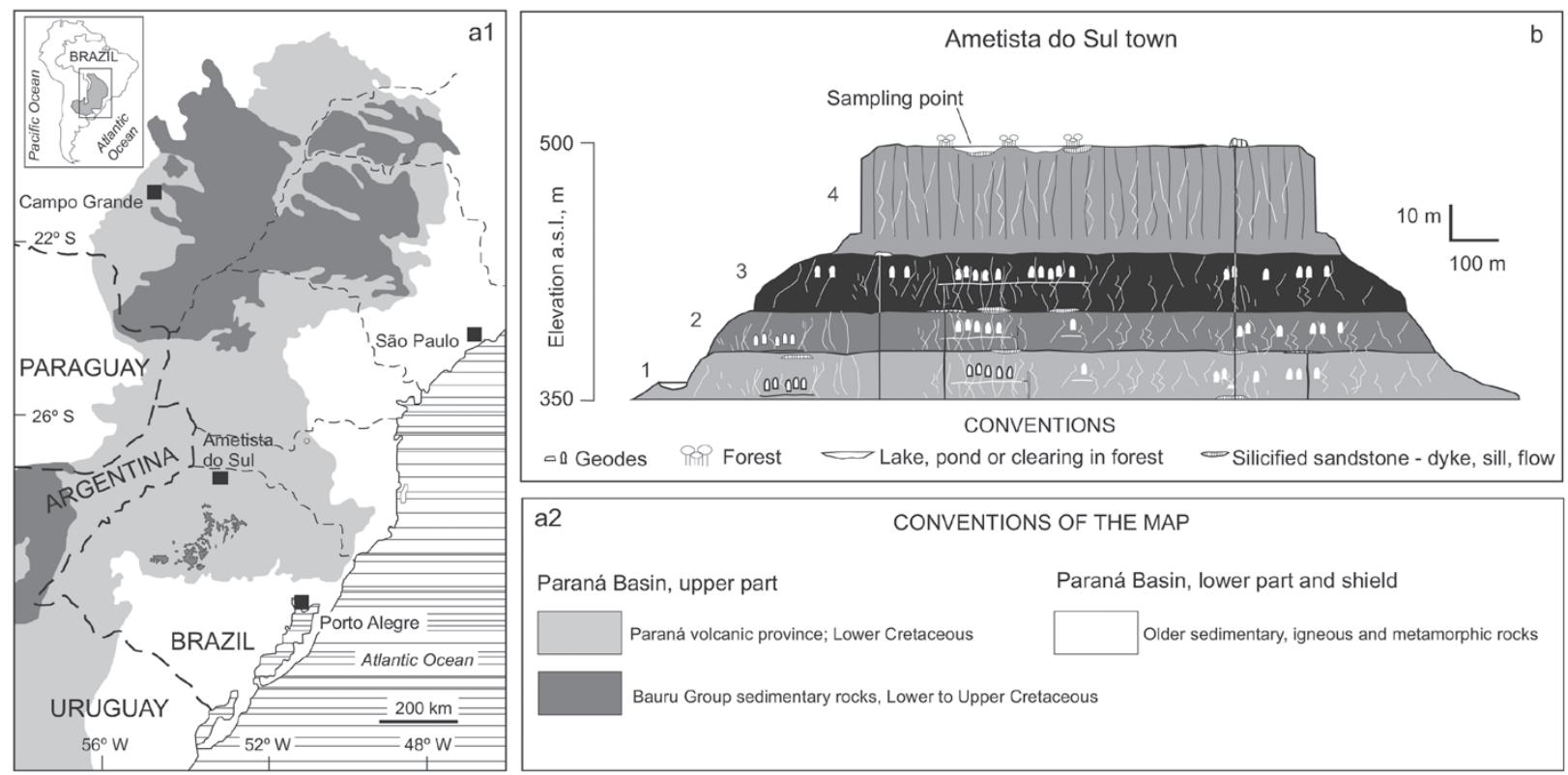

Fig. 1 - a1) location of Ametista do Sul; a2) map legend; b) model sections of lava units in the Ametista do Sul mining districts (adapted from Hartmann et al. 2010).

\section{MATERIALS AND METHODS}

SAMPLING

The sampling point $\left(27^{\circ} 22.373^{\prime} \mathrm{S} \times 53^{\circ} 11.901^{\prime} \mathrm{W}\right)$ is known as "Mina do Museu" because it is located immediately above an amethyst extraction mine. The site was originally selected with the aid of maps generated by satellite (e.g., Google-Earth) due to its isolation in the surrounding native woods. Interviews with local residents were essential to confirm the spontaneous nature of the surrounding vegetation of the pond.

At the time of sampling in autumn of 2009 (April), the pool area was not flooded, and its surface was dry and semi-consolidated due to a long drought in the region. Samples for different 
analyses were recovered from a $95 \mathrm{~cm}$-long sediment core collected manually from the center area of the pool. The sampling was performed with the assistance of a tractor backhoe that opened a trench of approximately $1.0 \mathrm{~m}$ of depth from the surface sedimentary level to the boundary with the underlying basalt. The corer consisted of a piece of PVC tube with a length of $1.0 \mathrm{~m}$ and a diameter of $7.0 \mathrm{~cm}$ that was previously cut into two halves. For sample collection, the convex side of the semi-split corer was pressed against the wall of the trench. When filled with sediment, the corer was sealed with a plastic film on both sides to prevent loss of moisture. The core was split into subsamples in the laboratory for sedimentary, geochemical and palynofacies analyses.

\section{GRANULOMETRIC ANALYSES}

Granulometric analysis was performed in the "Laboratóriode Sedimentologia, Centro deEstudos Costeiros e Oceânicos, Instituto de Geociências, Universidade Federal do Rio Grande do Sul (UFRGS)". Sieving and pipetting were carried out with class intervals of 1 and $1 / 4$ de phi respectively, according to the method proposed by Folk and Ward (1957).

\section{DATING}

Samples for carbon isotopic dating were collected at the lithological boundaries to create a consistent age-depth model. Three radiocarbon datings were performed, on the lower boundary (65 $\mathrm{cm} \mathrm{depth),}$ at the central part (40 cm depth) and at the upper boundary $(20 \mathrm{~cm}$ depth) of the clay-silty mud of Interval B. Acceleration Mass Spectrometry (AMS) at the Beta Analytic Radiocarbon Dating Laboratory (Miami, Florida, USA) was used for the analysis. The interpolated and extrapolated ages were calculated using the intercept of the mean conventional age interval in the calibration curve of ${ }^{14} \mathrm{C}$ (CALIB version 4.3; Stuiver et al. 1998). The unconsolidated surface sediment $(0-15 \mathrm{~cm})$ was not sampled because there were roots of recent plants which penetrated on soil and this could affect the resolution of the method of carbon dating $\left({ }^{14} \mathrm{C}\right)$. The top of the core corresponds to the soil surface where the sedimentary profile was collected and, because of this, was assigned age "Recent" to the core top.

\section{GEOCHEMISTRY}

The accumulation of $\mathrm{OM}$ in the sediments was estimated using total organic carbon (TOC) analyses. According to Tyson (1995), TOC analysis is a convenient method for determining the relative abundance of $\mathrm{OM}$ in sediments. The accumulation of $\mathrm{OM}$ is controlled by major factors such as primary productivity, water depth, and sediment grain size. The TOC is always controlled by three main variables: the input of $\mathrm{OM}$, the preservation of the supplied OM, and the dilution of the OM by sediment accumulation (Tyson 1995). The values of the TOC in marine rocks ranged from approximately $0.1 \%$ (deep-sea pelagic deposits) to 94\% (coals) (Tyson 1995).

The total organic carbon (TOC) and total sulfur (TS) analyses were carried out according to standards of ASTM D 4239 (American Society Testing and Materials, ASTM 2008) and NCEA-C-1282 (United States Environmental Protection Agency, U.S.EPA 2002). Following acidification to remove the carbonates, the TOC and ST analyses were made in all samples with a LECO SC 144 device at the Laboratory of Palynofacies and Organic Facies (LAFO).

\section{SAMPLE PREPARATION}

The material preparation for the palynofacies analyses was carried out using the standard non-oxidative palynological procedures described by Tyson (1995), Mendonça-Filho (1999) and Mendonça-Filho et al. (2002, 2010b). For the OM concentrate preparation procedure, the studied samples were ground to a size of approximately $2 \mathrm{~mm}$. The samples were treated successively to remove carbonates $(\mathrm{HCl} 37 \%$ for 
18h), silicates (HF 40\% for 24h), and neoformed fluorides ( $\mathrm{HCl} 37 \%$ for $3 \mathrm{~h}$ ). Between steps, the samples were washed with distilled water until the wash water was neutral. After this procedure, $\mathrm{ZnCl}_{2}$ (density $=1.9$ to $2 \mathrm{~g} / \mathrm{cm}^{3}$ ) was added and stirred, and the samples were centrifuged to separate the sulfides. The floated material was similarly washed and drops of $\mathrm{HCl}(10 \%)+$ distilled water were added to eliminate the heavy liquid. The isolated MO was sieved at $10 \mu \mathrm{m}$. After this procedure, strew slides were prepared with the organic residue.

The strew slides analyzed in this paper are stored in the "Laboratório de Palinologia, Instituto de Geociências, UFRGS" under the numbers MP-P 7119 to 7128 and MP-P 7481 to 7484 .

\section{PALYNOFACIES ANALYSES}

The palynofacies analyses involved the quantitative (counted from 300 to 500 particles) and qualitative (organic particle component identification) examinations of the OM component groups and subgroups. These examinations were achieved by means of microscopy techniques under transmitted white light and blue/ultraviolet incident light (fluorescence). The counts followed the OM groups and subgroups classifications proposed by Tyson (1995), Mendonça-Filho (1999) and Mendonça-Filho et al. (2002, 2010b, 2011). In this classification, the particulate organic matter (POM) is organized into three main groups according to their optical properties: phytoclasts, amorphous product and palynomorphs.

In the present paper, all OM without form and lacking sharp edges, angular contours or any type of feature permitting its classification in any other group of POM was classified as amorphous product (AP). Such particles most likely derived from algae or plant debris in an advanced state of degradation, which may have resulted from microbial action as in other transformation processes of POM that are active in the depositional environment studied or from both processes concurrently. The term "amorphous product" was chosen because of the exclusively continental origin of the sediment analyzed to avoid conflicts with the Amorphous Organic Matter (AOM), commonly related to marine environments or depositional systems that suffer the influence of eustatic variations.

According to Mendonça-Filho et al. (2011, p. 43), "theAmorphous Group consists of all particulate organic components that appear structureless at the scale of light microscopy; including phytoplankton derived amorphous organic matter (traditionally referred to as "AOM"), bacterially derived amorphous organic matter (also traditionally referred to as "AOM"), higher plant resins, and amorphous products of the diagenesis of macrophyte tissues".

The classification of the subgroups of palynomorphs was established based on the peculiarities of the studied environment in which only freshwater algae are present and are associated with spores and pollen grains of exclusively continental origin (Fig. 2).

\section{STATISTICAL TREATMENT}

Based on the quantitative analysis of the organic particulate components, a statistical treatment of the data was carried out using the variables described in Fig. 2. The absolute data were recalculated for percentage values (Table II) for discussion about dominance. All the variables were normalized and put on comparable scales in order to submit the samples to multivariate statistical analyses (cluster analysis). The correlation coefficient R-Mode is performed to check similarities among the variables (organic particles) and determinate the Palynofacies. The correlation coefficient Q-Mode, in turn, enables the observation of the degree of similarity between the samples in order to determine the Associations (depths) and, subsequently, the Intervals (ages). For generated de R-Mode and Q-Mode dendograms was used the same numeric data matrix which was submitted to Statistic Basic program, version 6.0 (Valentin 2000). 


\begin{tabular}{|c|c|c|c|c|}
\hline GROUP & \multicolumn{3}{|c|}{ SUBGROUP } & ABBREVIATION \\
\hline \multirow{7}{*}{ 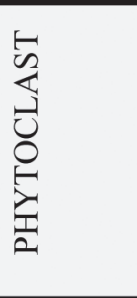 } & \multirow[t]{2}{*}{ Opaque } & \multicolumn{2}{|l|}{ Lath } & POL \\
\hline & & \multicolumn{2}{|c|}{ Equidimensional } & POE \\
\hline & \multirow[t]{5}{*}{ Translucent } & \multicolumn{2}{|c|}{ Structured } & PTS \\
\hline & & \multicolumn{2}{|c|}{ Not Structured } & PTNS \\
\hline & & \multicolumn{2}{|c|}{ Amorphous } & PTA \\
\hline & & \multicolumn{2}{|l|}{ Cuticle } & CUT \\
\hline & & \multicolumn{2}{|c|}{ Membrane } & MEMB \\
\hline \multirow{6}{*}{ 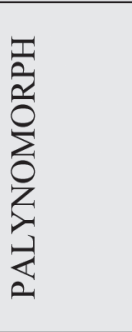 } & \multirow[t]{4}{*}{ Sporomorph } & \multirow[t]{2}{*}{ Spores } & Briophyte & \multirow[t]{2}{*}{ Spores } \\
\hline & & & Pteridophyte & \\
\hline & & \multirow{2}{*}{$\begin{array}{l}\text { Pollen } \\
\text { grains }\end{array}$} & Gymnosperm & \multirow[t]{2}{*}{ Pollen } \\
\hline & & & Angiosperm & \\
\hline & $\begin{array}{l}\text { Freshwater } \\
\text { microplankton }\end{array}$ & \multicolumn{2}{|r|}{$\begin{array}{l}\text { Botryococcus } \\
\text { (Chlorophyceae) }\end{array}$} & \multirow[t]{2}{*}{ Algae } \\
\hline & Incertae sedis & \multicolumn{2}{|r|}{ Pseudoschizaea } & \\
\hline \multicolumn{4}{|c|}{ AMORPHOUS PRODUCT } & AP \\
\hline
\end{tabular}

Fig. 2 - General classification of POM used in this work.

\section{RESULTS}

\section{PROFILE DESCRIPTION}

Visual observations associated with the granulometric analyses allowed for the identification of three sedimentary intervals from the base level $(95 \mathrm{~cm})$ to the surface unconsolidated level:

Interval $A$. Corresponds to the lower portion of the core $(65-95 \mathrm{~cm})$ and shows a predominance of fragmented basalts with yellowish-gray color occurring as coarse gravel mixed with sand and claysilty mud; this latter material most likely originated in superjacent levels and percolated through the basalt.

Interval $B$. Corresponds to the middle and more representative section of the core $(65-15 \mathrm{~cm})$ where a significant discordance is observed from the finer grained texture, granulometry and color patterns relative to interval $A$. This material is composed of a grayish and semi-compact mud that is texturally homogeneous, showing a few thin vegetal remains. Due to the great homogeneity of the sediment in interval B, only three samples were selected for granulometric analyses, named
Base $(65 \mathrm{~cm})$, Midst $(40 \mathrm{~cm})$ and Top $(20 \mathrm{~cm})$. The percentage of sand, silt and clay on the Base was $0.45 \%, 39.15 \%$ and $60.39 \%$, respectively. On the Midst sample, the percentage of sand $(0.04 \%)$ and clay $(55.86 \%)$ decreases, whilst the percentage of silt $(44.09 \%)$ increases. For the Top, the percentage of sand, silt and clay was, respectively, $0.11 \%$, $45.78 \%$ and $54.10 \%$. The granulometric analysis allowed for the classification of the sediment as a degraded clay-silty mud with a predominance of the clay fraction along the entire profile (average of 56.8 $\%)$. In addition, the fine grain size indicates a low energy depositional setting and the absence of any sedimentary structures suggests that the sediments were deposited under quiet lacustrine conditions.

Interval $C$. Represents the surface sediments of the core $(0-15 \mathrm{~cm})$ and corresponds to a brownish-gray soil showing thin rootlets and bioturbation.

Only B and C intervals were selected for geochemistry and palynofacies study because they consisted of sediments with a greater potential for preservation of organic matter. 


\section{RADIOCARBON DATING}

A chronological framework for the B interval sedimentary sequence was provided by the radiocarbon date (Table I, Fig. 3). A gradual low mass accumulation rate in the pond can be inferred based on the relationship of the long time interval with the short interval of sedimentation $(65 \mathrm{~cm})$. Additionally, the age of 8050 to 7950 years BP obtained from a 65 $\mathrm{cm}$ depth represents important information because it reflects the beginning of the pond sedimentation just overlying the basalt package which corresponds to the roof of the underlying amethyst mine and should represent the age of the pond.

\section{GEOCHEMICAL ORGANIC ANALYSIS}

The concentration of TOC is a fundamental parameter for describing the abundance of $\mathrm{OM}$ in sediments. The TOC concentrations are influenced by both the initial biomass production and the subsequent degree of degradation such that they integrate the different origins, delivery routes, depositional processes and consequent degrees of preservation of OM (Tenzer et al. 1997).

Throughout the T1 core the TOC values are relatively low, less than $1 \%$ in most intervals and gradually increase toward the top, where they reach the maximum value of $8.93 \%$ (Table II). Thus, the higher values of the TOC at the top of the interval may be a reflection of the vegetational evolution of the area or may be associated with the lower degradation suffered by the $\mathrm{OM}$ in the more recent levels. A similar evolution is observed for the total sulfur (TS) values, ranging from 0.01 to $0.09 \%$ towards the base-top of the core (Table II).

Low concentrations of the TOC and TS have been related to oxic phases; however, these values can vary independently under certain conditions (Tyson 2001). The low values of the ST indicate that sulfate-reducing processes, which are typical of anoxic environments, were not significant along the sedimentary deposition. This evidence confirms the relatively oxic conditions of the depo- sitional environment. According to Tyson (1995), continental aquatic environments contain a notably low concentration of dissolved sulfate compared with marine environments in which the sulfatereducing processes occur exclusively under anoxic conditions involving the activity of anaerobic bacteria. The ratio between the concentrations of the TOC and ST is high ( $>15)$ and typical of a freshwater environment, according to the model proposed by Berner and Raiswell (1984), despite the observation that the percentage of the TOC does not reach $1 \%$ in certain basal intervals.

Considering that finer sized sediments typically carry higher concentrations of OM, the low concentration of the TOC observed in the basal intervals of the studied core could be related to the slow rate of sediment accumulation, thereby causing longer exposure of the OM to processes of oxic degradation. This evidence is confirmed by the relationship of the long time interval with the short sedimentary interval observed in the 20 to $60 \mathrm{~cm}$ depth of the core.

Alternatively, the low levels of the TOC could be related to the lower input of terrigenous $\mathrm{OM}$ in the depositional system due to the low productivity of the environment. Thus, it can be inferred that at the start of the gossan sedimentation, the process of ecological succession from the surrounding area gradually evolved without sufficient vegetation to sustain a high productivity of $\mathrm{OM}$ in the initial portions of the interval. This latest hypothesis is ratified by the high concentrations of TOC and TS occurring in Interval $\mathrm{C}$, compared with the clay silty mud levels sampled in Interval B.

\section{PALYNOFACIES ANALYSIS}

The predominance of the phytoclast group (52.6\%) was observed in the studied succession, whereas the palynomorph group was the second most dominant $(39 \%)$ and the AP was last, with percentages lower than $8.4 \%$. The TOC concentrations of the sediments are regulated by the most abundant group, or in this case, the phytoclasts. 
TABLE I

AMS (Accelerator Mass Spectrometry) radiocarbon ages from the sediments of the T1 core (Mina do Museu). The analyses were performed by Beta Analytic, Inc.

\begin{tabular}{ccccccc}
\hline $\begin{array}{c}\text { Depth } \\
(\mathbf{c m})\end{array}$ & Lab. number & $\begin{array}{c}{ }^{13} \mathbf{C} /{ }^{\mathbf{1 2}} \mathbf{C} \\
\mathbf{( \% o )}\end{array}$ & $\begin{array}{c}\text { Conventional } \\
{ }^{14} \mathbf{C} \text { age BP }\end{array}$ & $\begin{array}{c}\text { Calendar age } \\
\text { cal yr BP } \\
\text { (median probability)* }\end{array}$ & $\begin{array}{c}\text { Calendar age } \\
\text { range } \\
\text { (cal yr BP)** }\end{array}$ & $\begin{array}{c}\text { Elevation } \\
\text { a.m.s.l. (m)*** }\end{array}$ \\
\hline 20 & Beta 295195 & -18.2 & $4860 \pm 30$ & 5584 & 5640 to 5580 & 500 \\
40 & Beta 295196 & -18.9 & $5440 \pm 40$ & 6205 & 6300 to 6190 & 500 \\
65 & Beta 299797 & -19.8 & $7200 \pm 40$ & 7963 & 8050 to 7950 & 500 \\
\hline
\end{tabular}

$\mathrm{BP}=$ before present, cal $=$ calibrated.

* Calibrated ages are calculated from SHCAL04 (McCormac et al. 2004);

** Calibrated ages are calculated from INTCAL 04 (Reimer et al. 2004) and Talma and Vogel (1993), which assumes a two-sigma error on radiocarbon measurements with an error multiplier of 1.0.

*** a.m.s.l. = actual altitude above mean sea level.

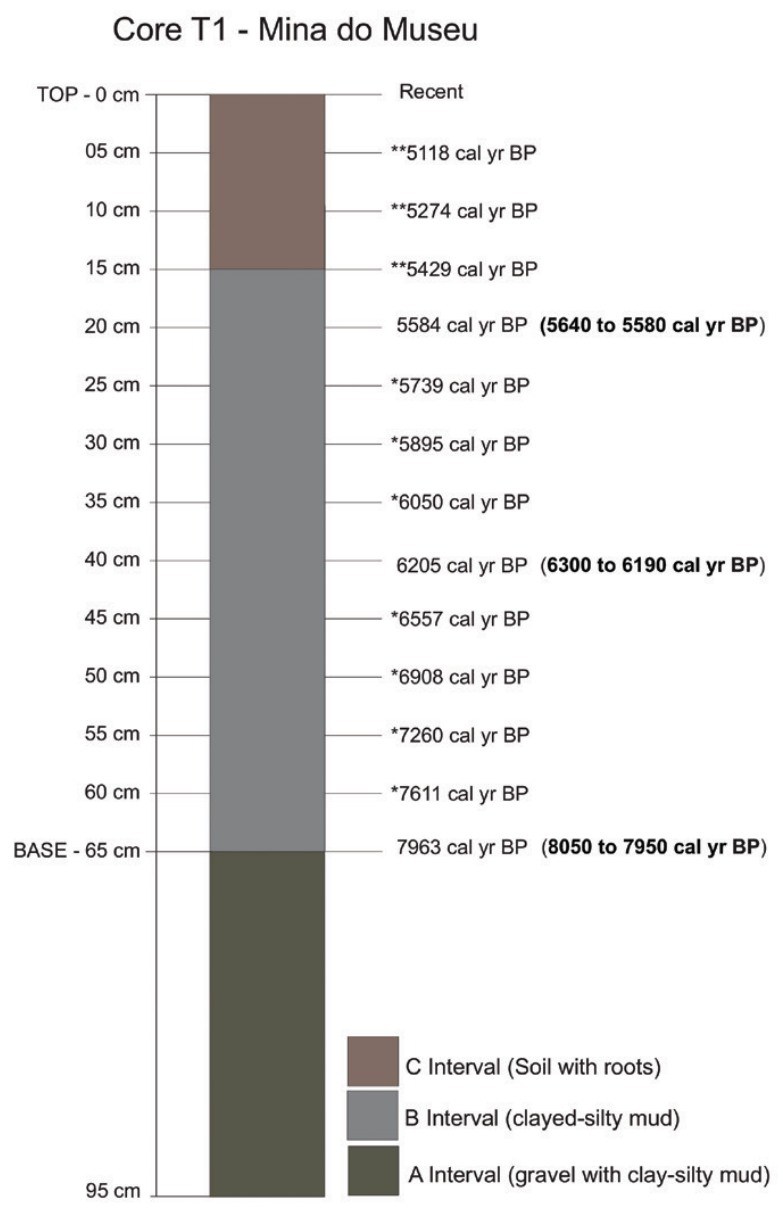

Fig. 3 - Chronological framework for the sedimentary profile of the T1 core (Mina do Museu) showing the calibrated radiocarbonic age (cal yr BP), the interpolated ages $(*)$ and the extrapolated ages $(* *)$. The analyses performed by Beta Analytic are highlighted in bold. The other ages are calculated as the median probability. 
TABLE II

Table showing the percentages of the TOC and ST and the percentages of the major groups and subgroups of the POM and of the averages of the sample groups. (*) Percentage value of the three main groups of POM related to total organic matter. $(* *)$ Percentage value of palynomorphs related to the total palynomorph group. Abbreviations are in accordance with Fig. 2.

\begin{tabular}{|c|c|c|c|c|c|c|c|c|c|c|c|}
\hline 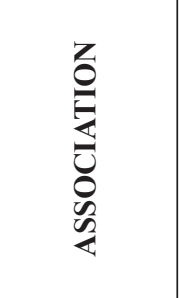 & 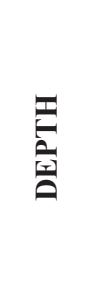 & 息 & ○ & 点 & 蒙 & 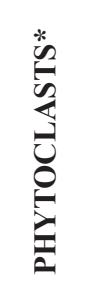 & 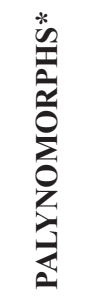 & 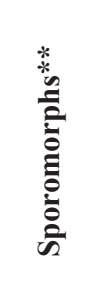 & 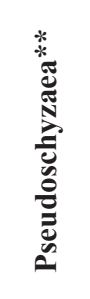 & 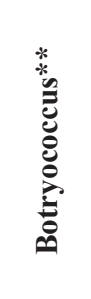 & 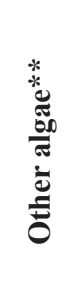 \\
\hline V & $0 \mathrm{~cm}$ & Recent & 8.93 & 0.09 & 7.68 & 53.54 & 38.79 & 100 & 0 & 0 & 0 \\
\hline AVERAGE & & & 8.93 & 0.09 & 7.68 & $\mathbf{5 3 . 5 4}$ & 39.79 & 100 & $\mathbf{0}$ & $\mathbf{0}$ & $\mathbf{0}$ \\
\hline IV & $5 \mathrm{~cm}$ & 5118 & 1.58 & 0.02 & 17.60 & 35.20 & 47.20 & 96.61 & 1.69 & 0.85 & 0.85 \\
\hline IV & $10 \mathrm{~cm}$ & 5274 & 1.18 & 0.03 & 13.94 & 56.49 & 29.57 & 64.23 & 4.07 & 30.89 & 0.81 \\
\hline IV & $15 \mathrm{~cm}$ & 5429 & 0.86 & 0.01 & 14.78 & 58.43 & 26.79 & 59.48 & 2.59 & 37.07 & 0.86 \\
\hline AVERAGE & & & 1.21 & 0.02 & 15.44 & 50.04 & 34.52 & 73.44 & 2.78 & 22.94 & 0.84 \\
\hline III & $20 \mathrm{~cm}$ & 5584 & 1.1 & 0.01 & 4.09 & 49.05 & 46.87 & 43.02 & 16.28 & 37.79 & 2.91 \\
\hline III & $25 \mathrm{~cm}$ & 5739 & 1 & 0.01 & 5.62 & 58.43 & 35.96 & 34.38 & 14.06 & 46.88 & 4.69 \\
\hline III & $30 \mathrm{~cm}$ & 5895 & 0.95 & 0.02 & 7.87 & 52.49 & 39.63 & 26.49 & 14.57 & 56.29 & 2.65 \\
\hline III & $35 \mathrm{~cm}$ & 6050 & 0.88 & 0.01 & 7.85 & 57.59 & 34.55 & 33.33 & 15.15 & 45.45 & 6.06 \\
\hline AVERAGE & & & 0.98 & 0.01 & 6.36 & 54.39 & 39.25 & 34.31 & 15.02 & 46.60 & 4.08 \\
\hline I & $40 \mathrm{~cm}$ & 6205 & 0.95 & 0.02 & 3.06 & 51.63 & 45.31 & 45.05 & 11.26 & 36.04 & 7.66 \\
\hline I & $45 \mathrm{~cm}$ & 6557 & 0.76 & 0.02 & 6.78 & 51.49 & 41.73 & 38.96 & 6.49 & 45.45 & 9.09 \\
\hline I & $50 \mathrm{~cm}$ & 6908 & 0.54 & 0.02 & 7.65 & 55.41 & 36.94 & 44.29 & 2.86 & 46.43 & 6.43 \\
\hline I & $60 \mathrm{~cm}$ & 7611 & 0.42 & 0.01 & 7.61 & 36.80 & 55.58 & 31.96 & 0.46 & 59.36 & 8.22 \\
\hline AVERAGE & & & 0.67 & 0.02 & 6.28 & 48.83 & 44.89 & 40.06 & 5.27 & 46.82 & 7.85 \\
\hline II & $55 \mathrm{~cm}$ & 7260 & 0.53 & 0.02 & 5.79 & 57.89 & 36.32 & 35.51 & 1.45 & 57.97 & 5.07 \\
\hline II & $65 \mathrm{~cm}$ & 7963 & 0.47 & 0.03 & 4.03 & 67.20 & 28.76 & 43.93 & 0.00 & 46.73 & 9.35 \\
\hline AVERAGE & & & 0.50 & 0.03 & 4.91 & 62.55 & 32.54 & 39.72 & 0.72 & 52.35 & 7.21 \\
\hline
\end{tabular}



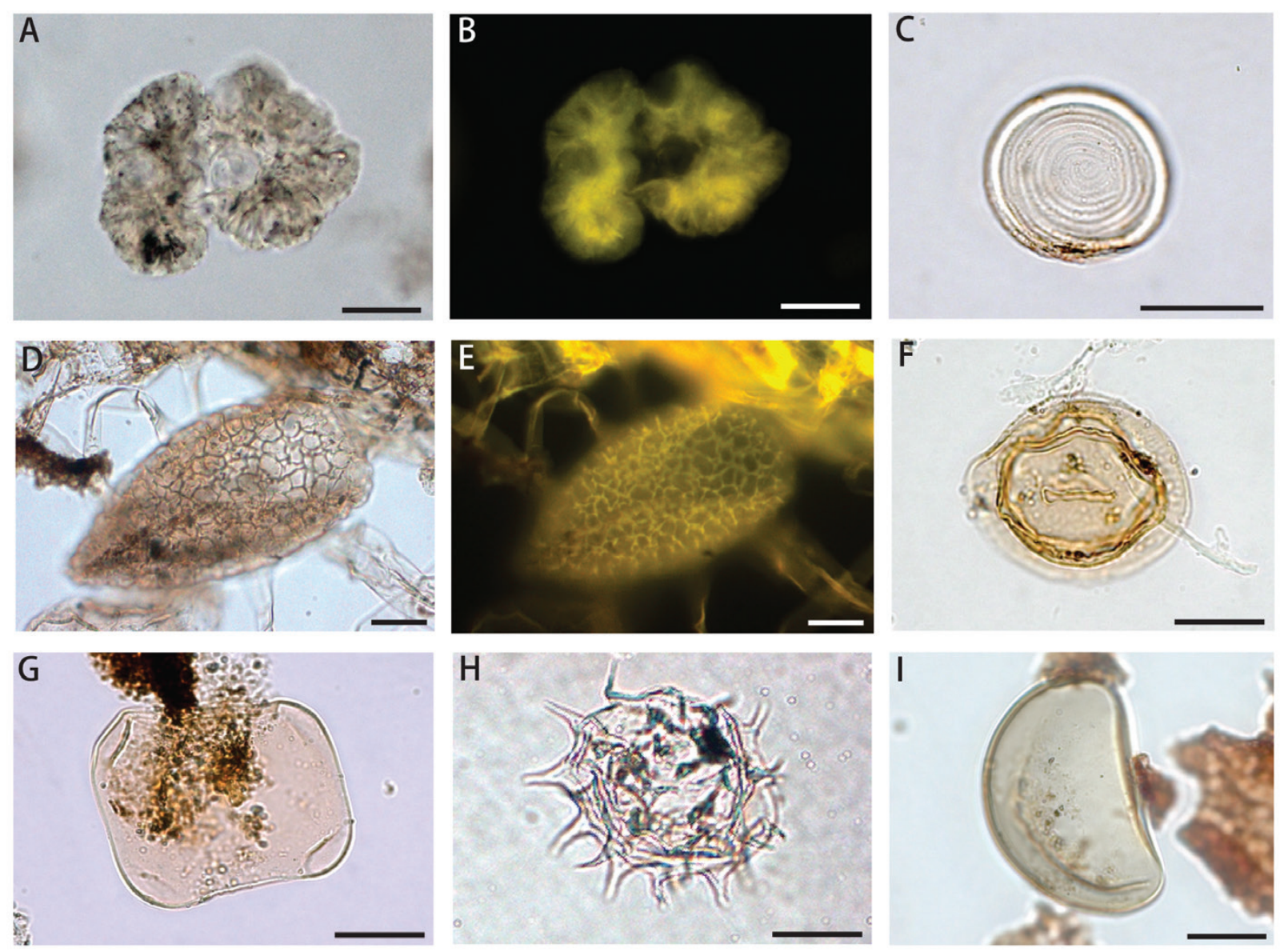

Fig. 4 - Palynomorph group. A-B, Botryococcus; C, Pseudoschizaea; D-E, Spyrogira; F, Debaria; G, Mougeotia; H, Desmídia; I, Pteridophyte spore. Scale bars: $20 \mu \mathrm{m}$.

Possibly due to the recent nature of the sediment layers analyzed, the fluorescence intensity of the particles was rather intense in general, varying from yellow to greenish-yellow (Botryococcus and other algae, Fig. 4) and from orange-yellow to orangebrown (phytoclasts and AP, Fig. 5).

\section{Hierarchical cluster analysis, R-mode}

According to the statistical R-Mode and using the Ward's method with 1-Pearson distance, the samples were classified into four main clusters of the particles, denoted as Palynofacies A, B, C and D (Fig. 6).

The Palynofacies A corresponds to the exclusively autochthonous components of lacustrine origin. The Palynofacies B is represented by non- woody allochthonous elements of plant origin and by Pseudoschizaea, incertae sedis group associated with autochthonous freshwater algae (Christopher 1976). The Palynofacies C corresponds to spores, parautochthonous elements, and amorphous components that are originally allochthonous. The Palynofacies D, in turn, is composed of woody phytoclasts and elements of terrestrial plant origin that are exclusively allochthonous.

The palynofacies show the distinctive stages of the analyzed depositional environment (corroborated by other statistical analyses that will be discussed below), beginning with a notably wet phase, wherein algalic and autochthonous elements predominate, progressing through transitional phases 

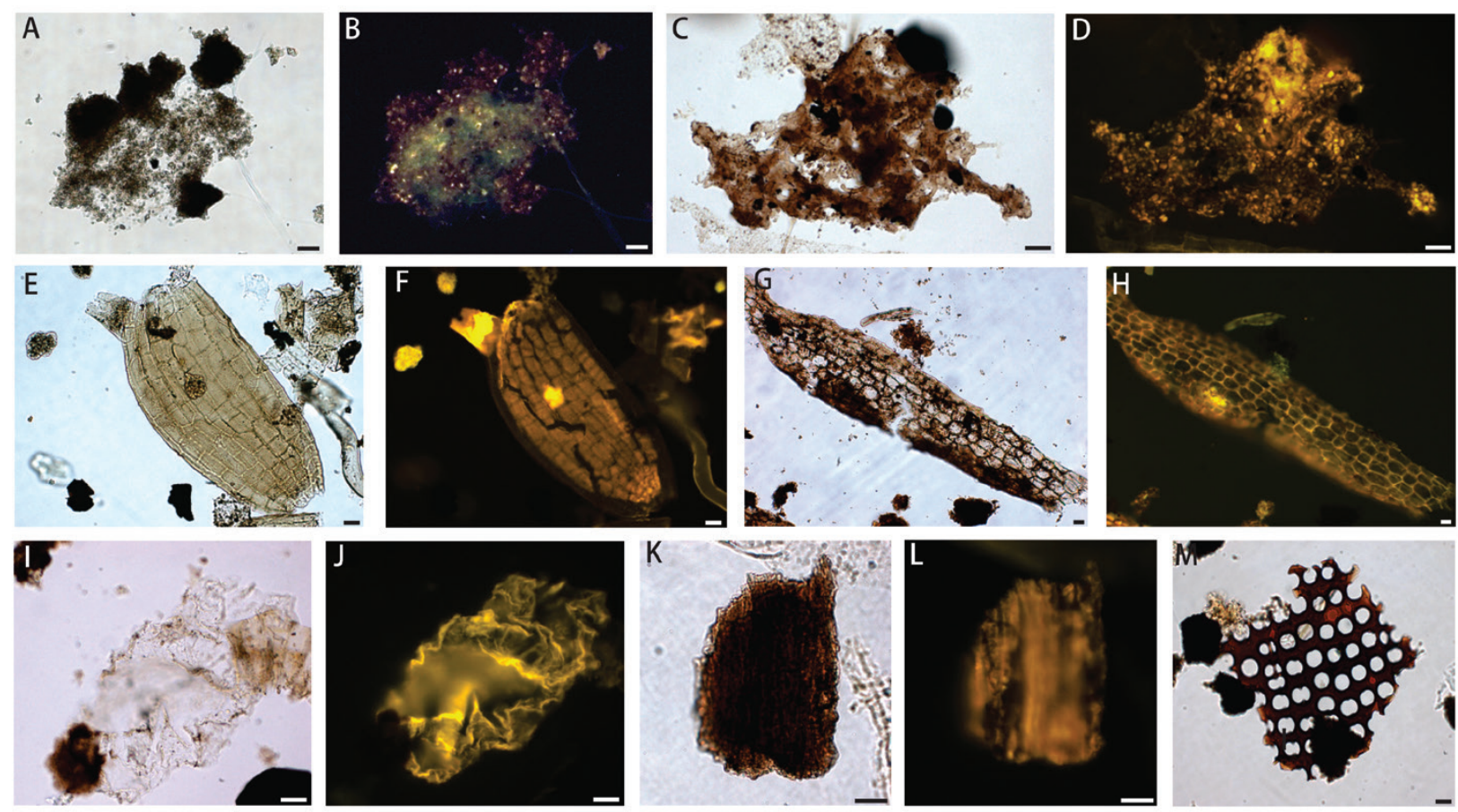

Fig. 5 - A-D, amorphous product (AP); E-M, phytoclast group. E-H, cuticles; I-J, membrane; K-M, phytoclasts. Scale bars: $20 \mu \mathrm{m}$.

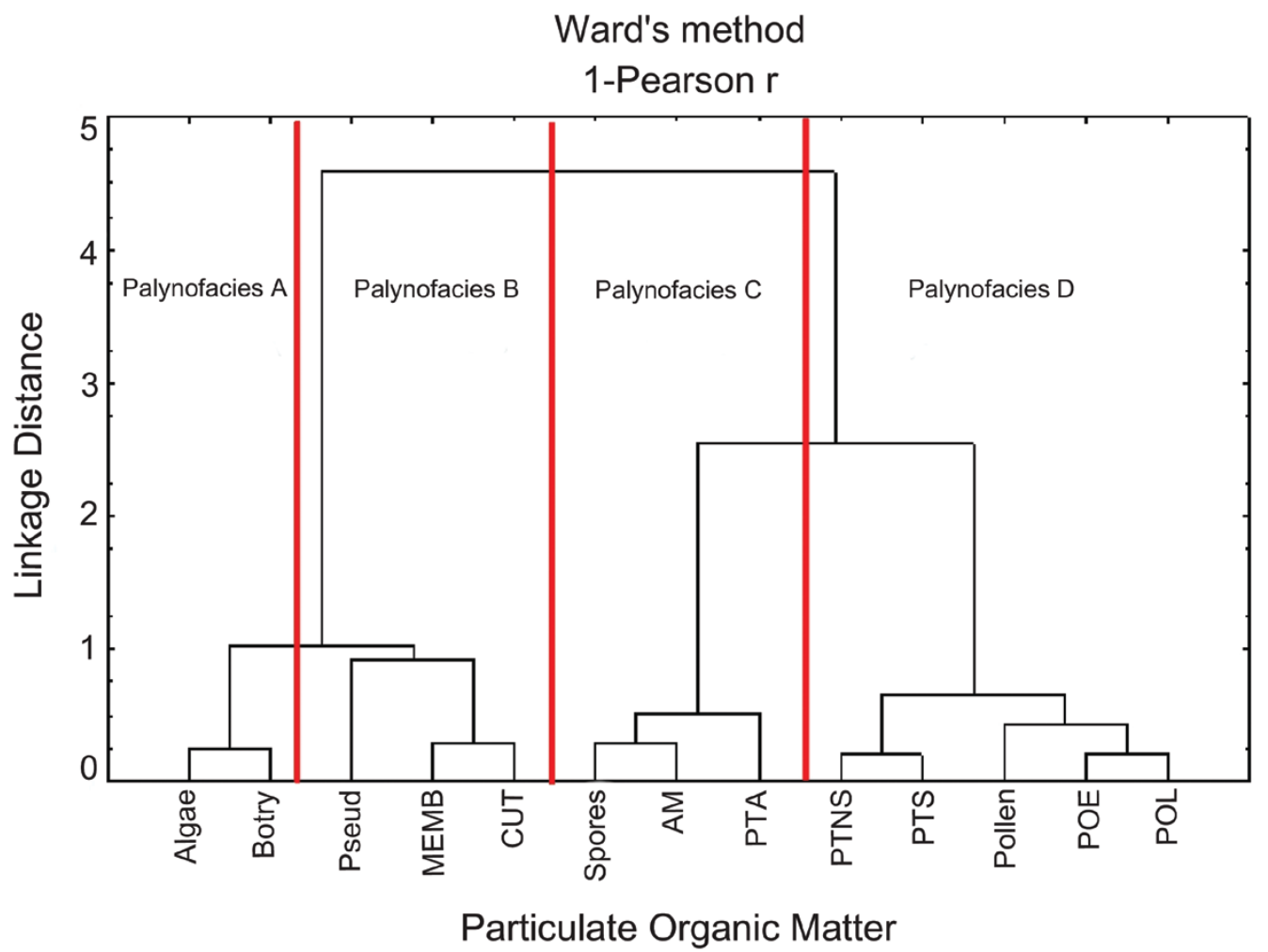

Fig. 6 - Dendrogram produced by cluster analysis R-mode for groups and subgroups of the POM from the T1 core (Mina do Museu). The red vertical lines divide the four palynofacies. Abbreviations are in accordance with Fig. 2. 
of relative moisture (evidenced by the presence of autochthonous and parautochthonous elements) with a gradual increase of terrigenous influence until the establishment of a dry phase with predominance of elements of terrestrial origin. The AandB palynofacies were divided because the frequency of Botryococcus and cuticles were inversely proportional in some basal intervals and produced different curves on the scatterplot (Fig. 8).

\section{Hierarchical cluster analysis Q-mode}

According to the statistical Q-mode and using the Ward's method with Euclidian distance, five main associations of the samples were observed and denominated as Association I, II, III, IV and V (Fig. 7 ), that are related to the palynofacies defined by the cluster R-mode (Fig. 6).

Association I is represented by samples of 40, 45, 50 and $60 \mathrm{~cm}$ (Fig. 7). The particles that reach the peak frequency in this association are the PTS, pollen grains, Botryococcus and other algae (Table II, Fig. 8), which are related to Palynofacies A (Botryococcus and other algae) and Palynofacies D (PTS and pollen) (Fig. 6). Phytoclasts predominate in most samples (average of $48.83 \%$ ), except for the $60 \mathrm{~cm}$ sample in which the palynomorphs are the dominant group (55.58\%), given the increased concentration of Botryococcus and other algae (Table II). The average value of the palynomorphs $(44.89 \%)$ is higher in this association in comparison with the others (Table II). The high frequency of algalic elements also constitutes a remarkable feature of this association which exceeds the frequency of the sporomorphs of terrestrial origin in all samples (Table II). The frequency of AP is low (average of $6.28 \%$ ) and reaches the lowest concentration $(3.06 \%)$ in this association (sample of $40 \mathrm{~cm}$, Table II). The pollen grains, although they achieve their peak concentration in this association

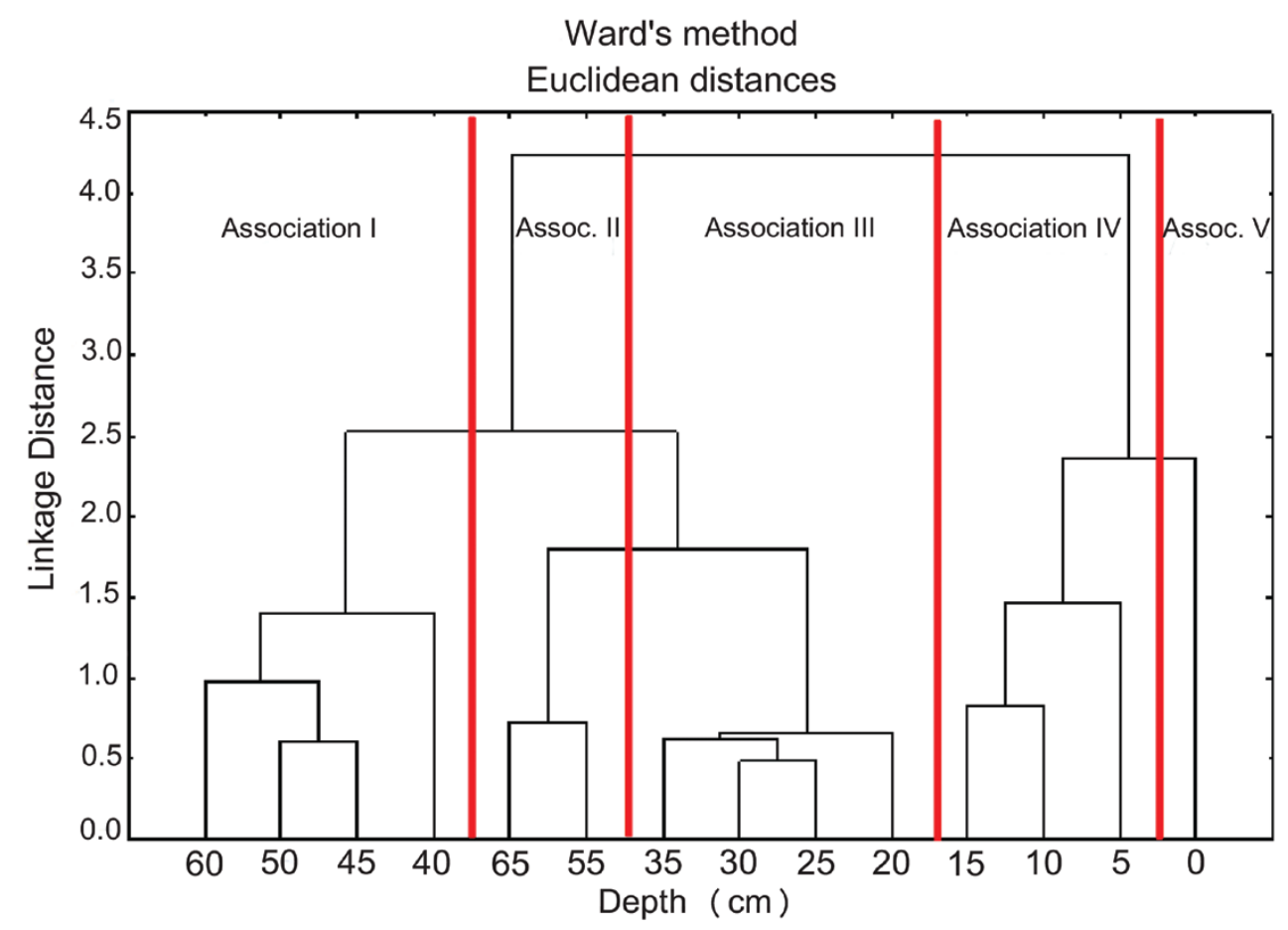

Fig. 7 - Dendrogram produced by cluster analysis Q-mode for groups and subgroups of the POM from the T1 core (Mina do Museu) in relation to depth. The red vertical lines divide the five Associations. Abbreviations are in accordance with Fig. 2. 


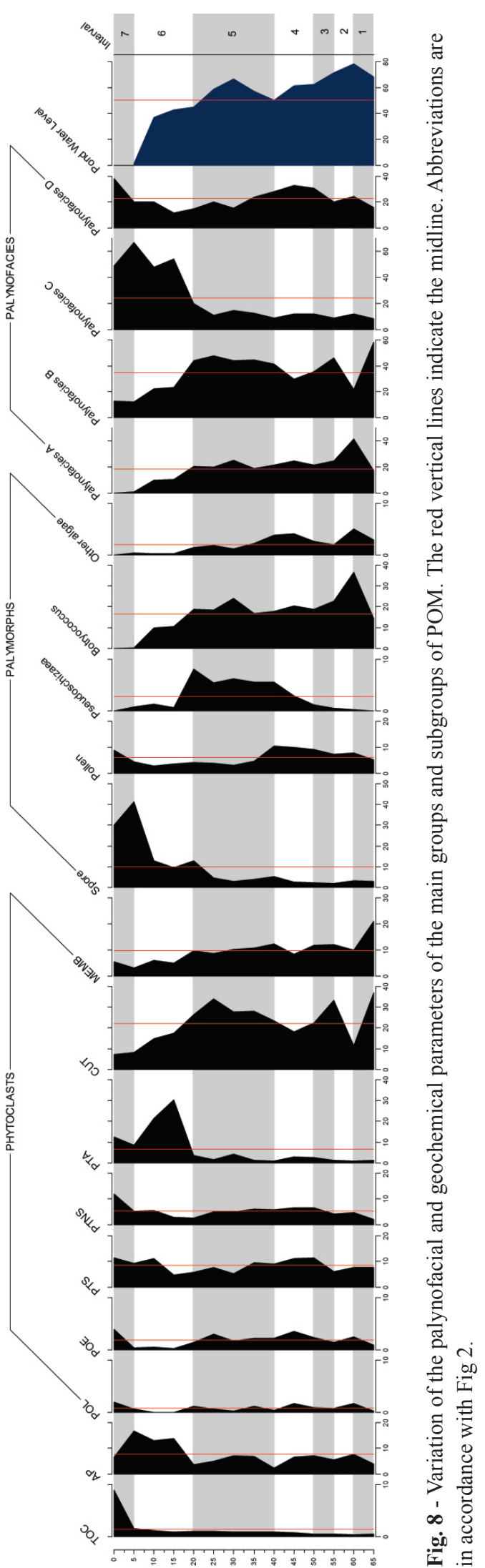


(sample of $40 \mathrm{~cm}$ ), do not predominate over the algae at any time. The peak frequency of the PTS, in turn, influences the prevalence of phytoclasts over palynomorphs in the samples of 45 and $50 \mathrm{~cm}$ (Table II). Broadly speaking, the change in the dominance of one group by another between the sample of $60 \mathrm{~cm}$ and the others that are components of this association occurs due to an increase in the input of terrestrial elements in the system from samples of 50-40 cm (Table II). This observation is attested by the increase in frequency of both components, the phytoclasts and the pollen grains. This input of allochthonous elements inside the pond may have contributed to the dilution of the autochthonous elements and was not necessarily related to significant fluctuations in water depth, because certain algalic elements (Pseudoschizaea and other algae) specifically increase in concentration in such samples (40 and $45 \mathrm{~cm}$, Table II).

Association II is represented by samples of 55 and $65 \mathrm{~cm}$ (Fig. 7). The particles that reach the peak frequency of this association are cuticles and membranes (Table II, Fig. 8), which are related to the Palynofacies B (Fig. 6). This association is characterized by the strong predominance of phytoclasts (average 62.55\%), reaching a peak frequency $(62.70 \%)$ in the sample of $65 \mathrm{~cm}$ (Table II). The averages of the palynomorphs (32.54\%) and the AP (4.91\%) are the lowest in comparison with other associations (Table II). Among the palynomorphs, the algalic elements (particularly Botryococcus and other algae) predominate over sporomorphs of terrestrial origin, particularly in the sample of $55 \mathrm{~cm}$, in which the frequency of spores decreases significantly (Table II). Pseudoschizaea, however, is absent or shows a notably low frequency in this association (Table II).

Association III is represented by samples of 20, 25, 30 and $35 \mathrm{~cm}$ (Fig. 7). Pseudoschizaea is the only particle that reaches peak frequency in this Association (Table II, Fig. 8) and is related to the Palynofacies B (Fig. 6). The phytoclasts group is predominant (average of 54.39\%), followed by the palynomorphs (average of $39.25 \%$ ) and the AP (average of 6.36\%) (Table II). Among the sporomorphs, algae are the dominant forms. Botryococcus predominates over the land esporomorfos in samples of 25, 30 and $35 \mathrm{~cm}$, achieving a high frequency $(56.29 \%)$ in the sample of $30 \mathrm{~cm}$ (Table II). However, in the sample of $20 \mathrm{~cm}$, the terrestrial sporomorphs begin to dominate, as evidenced by a relative increase in the frequency of fern spores. Nevertheless, the dominance of the autochthonous over the allochthonous elements in this association remains due to the increase in the frequency and the peak of Pseudoschizaea (15.02\%), which is rather high in comparison with other associations (Table II). In contrast to Pseudoschizaea, the average values of Botryococcus $(46.60 \%)$ and other algae $(4.08 \%)$ are reduced, which suggest a slightly different pattern of response to changes in moisture content by Pseudoschizaea (Table II).

Association IV is characterized by samples of 5, 10 and $15 \mathrm{~cm}$ (Fig. 7). The particles that reach the peak frequency in this association are AP, PTA and spores (Table II, Fig. 8), which are closely related to the Palynofacies C (Fig. 6). The average of the phytoclast group is $50.04 \%$ and the average of the palynomorph group is $34.52 \%$. The average of the AP group is $15.44 \%$ and represents the highest average achieved by the particles relative to other associations (Table II). The phytoclast group predominates in samples of 10 and $15 \mathrm{~cm}$ and is overtaken by the palynomorphs in the sample of $5 \mathrm{~cm}$, in which it reaches $47.20 \%$ due to a sharp increase in the frequency of fern spores (Table II). This association is characterized by a decrease of the algalic elements and the dominance of terrestrial sporomorphs, indicating significant changes in patterns of moisture and fluctuations in water depth, especially in the sample of $5 \mathrm{~cm}$, in which the frequency of Botryococcus decreases 
dramatically and is accompanied by a gradual reduction in the frequency of other algae (Table II, Fig. 8). Although Pseudoschizaea suffer a considerable reduction in this association, this reduction is proportionally less than that occurring with other algalic elements. This observation can be demonstrated in the sample of $5 \mathrm{~cm}$, in which the frequency of Pseudoschizaea surpasses Botryococcus (Table II, Fig. 8). Such data suggest that environmental changes influenced the decrease of all algalic elements but were subtler with regards to Pseudoschizaea. The increase in the frequency of AP and PTA may have influenced the moderate increase in the concentration of TOC, because such particles tend to contribute to the high contents of organic carbon in the system due to their more advanced stage of molecular degradation.

Association V is represented by the shallow sample of the core (Fig. 7). The particles that reach the peak frequency in this association are POL, POE and PTNS (Table II, Fig. 8), which are related to the Palynofacies D (Fig. 6). In this association, the dominance of the phytoclasts $(53.54 \%)$ occurs, followed by the palynomorphs $(38.79 \%)$ and the AP (7.68\%) (Table II). Among the palynomorphs, the sporomorphs derived from terrestrial macrophytes completely dominate this association, because the algae disappears as a result of a marked alteration in the moisture pattern (Table II). The fern spores remain dominant, although they suffer a subtle reduction in their frequency relative to the immediately preceding sample ( $5 \mathrm{~cm}$, Table II, Fig. 8 ), followed by angiosperm pollen, which increase their frequency in this sample in comparison with previous samples (5-35 cm, Table II). The exclusive occurrence of terrestrial esporomorfos in this Association discloses the establishment of the driest stage concomitant with the changes in the vegetational dominance of the area. The high frequency of woody phytoclasts in this sample exerts strong influences on the high levels of the TOC. However, the peak frequency of the opaque phytoclasts in the most recent portion of the analyzed intervals may be indicative of anthropogenic interference on the system.

Paleo-environmental Characterization based on Intervals generated by cluster analysis Q-Mode

Based on the associations generated by cluster analysis (Q-mode), the sedimentary section (Fig. 2) was subdivided into seven intervals (Fig. 8), from the base to the top of the core, with the aim of inferring the hydrological fluctuation during the time interval between 8050 years BP to the present day for the pond and surrounding area, influenced by autochthonous and allochthonous particles (Table II). Estimations of the pond water level were constructed based on the frequency of Botryococcus and other algae.

Interval 1 (7963 cal yr BP, Table II, Fig. 8) corresponds to Association II (65 cm depth) and is marked by the peak of cuticles and membranes, which are particles related to Palynofacies B. The predominance of Botryococcus and other algae over the terrestrial sporomorphs indicates the existence of a body of water, with a predominance of wet periods and strong contribution of terrigenous elements, especially unlignified phytoclasts.

Interval 2 (7611 cal yr BP, Table II, Fig. 8) corresponds to Association I (60 cm depth). The particles that reach their frequency peak in this range are Botryococcus and other algae related to Palynofacies A. This interval marks the highest water depth reached by the pond. Considering the altitude of the paleo-environment and the absence of fluvial inference, it is possible to infer a period of wetness marked by a high rainfall periodicity.

Interval 3 (7260 cal yr BP, Table II, Fig. 8) corresponds to Association II (55 cm depth). In this interval of Association II there is a moderate increase in the frequency of cuticles and membranes, particles related to the Palynofacies B. In this interval, the environmental conditions that occurred were similar to those inferred for Interval 1. However, the higher frequency of Botryococcus (relative to the interval of 
$65 \mathrm{~cm}$ depth) suggests a higher water depth, which is a reflection of the moisture peak that occurred in the previous interval $(60 \mathrm{~cm})$.

Interval 4 (6908 to 6205 cal yr BP, Table II, Fig. 8) corresponds to Association I. The particles that reach their frequency peak in this interval $(50-40 \mathrm{~cm})$ are PTS and pollen grains, related to Palynofacies D. Although this interval reveals an increase in the input of terrigenous elements within the pond, the saturation level of the water remains relatively constant because it continues to harbor a high frequency of algalic elements.

Interval 5 (6050 to 5584 cal yr BP, Table II, Fig. 8) corresponds to Association III and is characterized by a peak frequency of Pseudoschizaea, particle related to the Palynofacies B. In this interval, the frequency of Botryococcus is high (especially in the interval of $30 \mathrm{~cm}$ ), up to a depth of $25 \mathrm{~cm}$. Thereafter, the predominance of autochthonous elements over allochthonous elements remains solely due to the high concentration of Pseudoschizaea. The saturation level of the water reaches a peak at $30 \mathrm{~cm}$ and decreases until it reaches a depth of $20 \mathrm{~cm}$, at which point a marked change appears in the rainfall patterns and moisture regulators because the rate of Botryococcus and other algae tends to decrease progressively toward the top. In this interval, Pseudoschizaea behave slightly differently, reaching a high frequency precisely at this level. This observation allows us to speculate that this genre, in addition to being more resistant to drier periods, may play a role in the successional process of vegetation because the terrestrial sporomorphs begin to prevail in the top intervals. This evidence agrees with the observations of van Gell (1978) and van Gell and van der Hammen (1978) in that certain algalic taxons can act as biological markers of transitional intervals. However, Scott (1992) observed that Pseudoschizea is a common form in relatively warm areas of the world in recent environments where moisture is available and can possibly indicate local seasonal drying. It is possible that, the variation in water depth that will result in the intermittent pattern of the pond starts to become more meaningful from the final portion of the interval $(20 \mathrm{~cm})$ in which the alternation between periods of greater and lesser moisture seems to acquire a seasonal pattern.

Interval 6 (5429 to 5118 cal yr BP, Table II, Fig. 8) corresponds to Association IV and is characterized by the peak frequency of AP, PTA and spores, particles that compose the Palynofacies C. This interval is characterized by a considerable reduction in algalic elements, and consequently, in the water depth. The intermittent pattern of the pond was possibly established from this interval when the level of rainfall that flooded the pond constantly decreased or deregulated, reducing the capacity of the water depth to sustain a high algalic biomass. From a depth of $5 \mathrm{~cm}$, the autochthonous elements suffer a drastic reduction in frequency, resulting in their disappearance at the next level and in the establishment of drier periods characterized by erratic rainfall. In contrast, the dominance of fern spores over the other palynomorphs suggests the continuity of wet conditions that were insufficient to maintain a water depth capable of sustaining the same algalic biomass of the initial intervals (65-20 $\mathrm{cm}$, Table II, Fig. 8). Furthermore, the dominance of terrestrial palynomorphs in this association, which persists until the top of the profile, suggests that the ecological succession of the area was conditioned by environmental and climatic changes that were conducive to vegetational evolution in the areas surrounding the pond. This scenario led to a biomass deposition that was more abundant and diverse than that represented in the basal levels.

Interval 7 (Recent, Table II, Fig. 8) corresponds to Association $\mathrm{V}$, characterized by peak frequencies of particles such as POL, POE and PTNS that are related to Palynofacies D. This interval is marked by the disappearance of the algalic element, which indicates the consequent absence of water depth. This scenario corresponds to the situation in the study area at the sampling time because this interval 
corresponds to the sample at the top of the core (Fig. 8). This interval possibly involves the most recent years of the pond, which reflect a relative decline in the rainfall frequency in the region, rendering it unable to maintain a sufficient water depth to sustain an algalic biomass but with a humidity level sufficient for the persistence of a high frequency of spores of parautochtonous origin. From the establishment of the intermittent pattern of the pond, the variations in the thickness of the water depth begin to interfere with the preservation of algalic elements, rendering them more exposed to degradation. Comparing the age of the top core sample (Recent) with the sample of $5 \mathrm{~cm}$ (5118 cal yr BP) it is possible to observe a large time interval that could be explained in three possible ways, not necessarily mutually exclusive of each other: (1) the rate of sedimentary deposition was extremely slow, (2) the sedimentation was interrupted; (3) an erosive event occurred. Although it is not possible to observe an erosive boundary between the layer of $5 \mathrm{~cm}$ and the top, it is possible to infer that the dynamics of sedimentation of pond was dramatically altered by a decline in the rainfall frequency that resulted in the establishment of the intermittent pattern of the pond, which corroborates, with the climatic events reported.

Alternatively, the reduction of the water level may also be linked to the sedimentary filling of the pond over the years. Currently, the pond is most evident during the rainiest months, but its prevailing depth is possibly lower than in the initial intervals of the sedimentation. According to Esteves (2011), lakes are generally not permanent features of the landscape, and their disappearance over geologic time is linked to phenomena such as the accumulation of organic matter and the deposition of sediments. Ponds have a short durability in the geological scale, and their destiny is to succumb to their own sedimentary metabolism.

\section{DISCUSSION}

The plotted curve of the pond water level (Fig. 8) provides evidence that there were significant changes in the level of aqueous saturation of the pond over the last 7963 years BP (8050 to 7950 cal yr BP), which resulted in a reduced water depth and in an intermittent flood pattern of the pond, such as that currently observed. The present pattern, however, was not prevalent in the past, when the higher levels of aqueous saturation were maintained in the pond despite certain water-level oscillations, which are attributed to possibly more intense rainfall due to the wetter periods that prevailed in the past. The more conspicuous alteration of the wetness patterns begins at 5584 years $\mathrm{BP}(20 \mathrm{~cm}$ depth $)$ and intensifies from 5118 years BP ( $5 \mathrm{~cm}$ depth) up to recent times. This curve shows a trend stemming from the establishment of drier periods in the present-day, which constitutes evidence that could be linked to larger-scale climate changes in the region.

The higher precipitation events inferred by the palynofacies analyses in South Brazilian inland pond sediments occurring between 7963 to 7260 years BP can be related to the "Bond events" (especially the 8.2 and 7.4 ka events). The process of water accumulation in the gossan and the sedimentation of the pond were consequences of increased rainfall at approximately 8000 years BP.

Stríkes et al. (2011), based on the high resolution oxygen isotopic records of Southeastern Brazilian speleothems (1.3 to $10.2 \mathrm{Kyr}$ B.P) are synchronous with those obtained by Bond et al. (1997). The abrupt decreases in the ${ }^{818} \mathrm{O}$ values associated with increased precipitation in central eastern Brazil, according to Stríkes et al. (2011), closely correspond to an anomalously cold North Atlantic period during the Bond events. This observation demonstrates that the slowdown of the Atlantic meridional overturning circulation (AMOC) associated with freshwater pulses in the North Atlantic can promote abrupt changes in monsoonal precipitation in South America, which is potentially influenced by feedback processes.

Based on Quaternary sediments of a paleolagoon in Southeastern Brazil, Sallum et al. (2012) found a relationship with the $8.2 \mathrm{ka}$ event. 
The decadal scale anomalous oscillations in the sediments occurred between 9400 and $7500 \mathrm{cal} \mathrm{yr}$ $\mathrm{BP}$ and were correlated with long- and short-term natural events that generated high sedimentation rates, mainly between 8385 and 8375 cal yr BP (10 $\mathrm{cm} / \mathrm{yr})$. These results suggest that a modern-day short-duration North Atlantic climatic event, such as the $8.2 \mathrm{ka}$ event, could affect the environmental equilibrium in South America and intensify the South American summer monsoon.

According to Sallum et al. (2012), the 8.2 ka event was characterized by effects of short duration, approximately of a few hundred years, and the data obtained for the southeast of Brazil suggest that the event should have significantly affected the environmental conditions in the coastal area. Such anomalies show a high degree of correlation with cooler conditions associated with the North Atlantic $8.2 \mathrm{ka}$ event, which appears to have affected the environmental equilibrium in South America and intensified the South American summer monsoon. In Brazil, this event would have increased local precipitation and humidity as well as the sea level rise.

The record of a period of high humidity associated with the Bond events is of great importance related to the observation that the global extent of this event is still not well-known because the paleo-climatic records are still quite scarce in Brazil (Cheng et al. 2009, Stríkes et al. 2011, Sallum et al. 2012). Selected data for this period of time were not correlated to the Bond events by other authors (especially $8.2 \mathrm{ka}$ event), possibly due to small differences between the radiocarbon ages obtained, which result in uncertainties in the ${ }^{14} \mathrm{C}$ reservoir age corrections (Salgado-Labouriau et al. 1998, Behling 1998, Behling et al. 2004, 2005, Medeanic and Silva 2010). Furthermore, the radiocarbon ages are not always calibrated or the calibration methods used are not the most adequate.

An increase in rainfall was also inferred in the interval of 5895 years BP (30 cm depth), which has not been directly related to the cycles reported by Bond et al. (1997, 2001). According to Carlson et al. (2008), differences in the climate response to typical Northern Hemisphere cold events throughout the Holocene might be the result of glacial boundary conditions that persisted until 7.0 ka years BP. The 5.9 ka event reported in this work could be a consequence of intrinsically driven and abrupt ecological changes. These changes, as indicated by Williams et al. (2011), are strongly controlled by local biotic and abiotic processes and also by localized disturbances and climatic events.

\section{CONCLUSION}

Palynofacies and geochemical organic analyses have proved to be powerful tools in the paleo-environmental and paleo-climatic study of a Holocene continental inland pond in southern Brazil. The study produced the following conclusions:

1 - Although the granulometric texture of the samples favors the preservation of organic compounds, the relatively low concentrations of TOC and TS at the lower and middle portion of the section reflect an oxic setting in the pond due to a low to moderate sedimentation rate. However, the higher values of the TOC at the upper portion of the section can be related to the lesser degradation suffered by $\mathrm{OM}$ at the latest levels or may be a reflection of the vegetational evolution of the area. The ratio between the concentrations of TOC and TS is high and is typical of freshwater environments.

2 - The predominance of phytoclasts indicates that this group controls the organic carbon content of the sediments of almost all intervals. The palynomorphs are the second most dominant group and the AP is the least abundant group.

3 - The saturation level of the pond remained relatively constant from 7963 to 5584 years BP, when changes in the patterns of moisture created a drier environment and resulted in an intermittent pattern in the water depth that currently exists at the site.

4 - Fluctuations in water depth are inferred from the frequency of Botryococcus and other algae, 
which tend to decrease progressively toward the top where the autochthonous elements are replaced by parautochthonous (spores) and allochthonous (pollen grains) elements.

5 - Pseudoschizaea appears to be relatively more resistant to dry periods than other algalic elements and seems to act as a biological marker of the transitional intervals related to seasonal drying.

6 - Although the predominance of spores in the most recent intervals indicates the persistence of a certain amount of moisture, this moisture was not sufficient for the maintenance of the same algalic biomass that prevailed in the pond during the older intervals. Concurrently, the increase in the biomass input from the terrestrial system could be related to the reduction in the saturation level of water that may have promoted the densification of the surrounding vegetation.

7 - The increase in the frequency of spores and pollen grains in the topmost intervals suggests the establishment of terrestrial vegetation surrounding the pond that was more abundant and diverse than that represented at the basal levels (dominated by algae). This change in palynomorph composition may be a reflection of the process of ecological succession of vegetation.

8 -An increased rainfall event detected between 7963 to 7260 BP, which was responsible for the beginning of the processes of water accumulation in the gossan and the sedimentation of the pond, can be related to the "Bond events" (8.2 and 7.4 ka events).

9 - The present results are of great importance for understanding the global extent of the "Bond events", which are still not well known for Brazil, and demonstrate the need for new studies to improve the understanding of global climate change and their local and regional environmental impacts.

\section{ACKNOWLEDGMENTS}

The authors are grateful to the Prefeitura Municipal of Ametista do Sul, to the Cooperativa de Garimpeiros do Médio Alto Uruguai (COOGAMAI) for their support and to the owners of the mines for permission to collect the core samples. This work was a component of a $\mathrm{PhD}$ thesis at Programa de Pós-Graduação em Geociências, Universidade Federal do Rio Grande do Sul, Brazil. GTGM acknowledges scholarship support from Conselho Nacional do Desenvolvimento Científico e Tecnológico (CNPq) of the Brazilian Government. The $\mathrm{CNPq}$ financially supported the investigation through project $n^{\circ}: 401755 / 2010-0$.

\section{RESUMO}

Este artigo apresenta os resultados quantitativos e qualitativos obtidos a partir de análises de palinofácies e geoquímica realizadas em um testemunho que abrange aproximadamente 8.000 anos de sedimentação de um alagado de altitude localizado no distrito mineiro de Ametista do Sul, sul do Brasil. O principal objetivo deste artigo é analisar a importância paleoclimática e paleoambiental dessas análises. $\mathrm{O}$ isolamento hidrológico torna este alagado climaticamente sensível às variações do regime pluviométrico e isso permitiu inferir eventos de chuva durante o início do Holoceno, que foi responsável pelo início dos processos de acumulação de água no gossan e sedimentação do alagado. Mudanças no padrão de umidade ao longo do tempo tornaram o ambiente mais seco, resultando no padrão intermitente de profundidade de água que existe atualmente no local. As flutuações na profundidade da água são inferidas a partir da frequência de Botryococcus e outras algas, que tendem a diminuir progressivamente em direção ao topo, onde os elementos autóctones são substituídos por elementos parautóctones e alóctones. Pseudoschizaea, por sua vez, parece atuar como um marcador biológico destes intervalos de transição. Estes resultados são de grande importância para a compreensão da extensão das mudanças climáticas e seus impactos ambientais em nível regional e global.

Palavras-chave: ambiente continental, alagado, matéria orgânica, análise de palinofácies, carbono orgânico total, enxofre total. 


\section{REFERENCES}

ASTM - AMERICAN SOCIETY FOR TESTING AND MATERIALS. 2008. Standard test methods for sulfur in the analysis sample of coal and coke using high-temperature tube furnace combustion methods ASTM 4239. Available on http://engineers.ihs.com/documents/abstract/NWETIBA.

ARAÚJO LM, FrANÇAAB AND POTTER PE. 1999. Hydrogeology of the Mercosul aquifer system in the Paraná and ChacoParaná Basins, South America, and comparison with the Navajo-Nugget aquifer system, USA. Hydrogeol J 7: 317-336.

BAKer PA, Fritz SC, GARLAND J AND EKDAhL E. 2005. Holocene hydrologic variation at Lake Titicaca, Bolivia/ Peru, and its relationship to North Atlantic climate variation. J Quaternary Sci 20: 655-662.

Baker PA, Seltzer Go, Fritz SC, Dunbar RB, Grove MJ, TAPIA PM, CRoss SL, Rowe HD AND BRODA JP. 2001. The history of South American tropical precipitation for the past 25,000 years. Science 291: 640-643.

BEHLING H. 1998. Late Quaternary vegetational and climate changes in Brazil. Rev Palaeobot Palyno 99: 143-156.

Behling H, Pillar VP AND Bauermann SG. 2005. Late Quaternary grassland (Campos), gallery forest, fire and climate dynamics, studied by pollen, charcoal and multivariate analysis of the São Francisco de Assis core in western Rio Grande do Sul (southern Brazil). Rev Paleobot Palyno 133: 235-248.

Behling H, Pillar VP, ORLÓci L AND BAUERMANN SG. 2004. Late Quaternary Araucaria forest, grassland (Campos), fire and climate dynamics, studied by high-resolution pollen, charcoal and multivariate analysis of the Cambará do Sul core in southern Brazil. Palaeogeogr Palaeoclimatol Palaeoecol 203: 277-297.

BERNER RA AND RAISWELL R. 1984. C/S method for distinguishing freshwater from marine sedimentary rocks. Geology 12: 365-368.

Bond G, Kromer B, Beer J, Muscheler R, Evans MN, SHOWERS W, HOFFMANN S, LOTTI-BOND R, HAJdAS I AND BONANI G. 2001. Persistent solar influence on North Atlantic climate during the Holocene. Science 294: 2130-2136.

Bond G, Showers W, Cheseby M, Lotti R, Almasi P, Demenocal P, Priore P, Cullen H, Hajdas I AND BONANI G. 1997. A pervasive millennial-scale cycle in North Atlantic Holocene and glacial climates. Science 278: 1257-1266.

Boussafir M, SifEddine A, JACOB J, Foudi M, CORDEIRO RC, Albuquerque Als, Abrao JJ AND TurcQ B. 2012. Petrographical and geochemical study of modern lacustrine sedimentary organic matter (Lagoa do Caçó, Maranão, Brazil): Relationship between early diagenesis, organic sedimentation and lacustrine filling. Org Geochem 47: 88-98.

Carlson AE, Legrande AN, Oppo DW, CAME RE, Schmidt GA, ANSLOW FS, LICCIARDI JM AND OBBINK E. 2008. Rapid early Holocene deglaciation of the Laurentide ice sheet. Nature Geosci 1: 620-624.
Carvalho MA, Mendonça-Filho JG and Menezes TR, 2006a. Palaeoenvironmental reconstruction base don palynofacies analysis of the Aptian-Albian succession of the Sergipe Basin, Northeastern Brazil. Mar Micropaleontol 59: 56-81.

Carvalho MA, Mendonça-Filho JG And Menezes TR. 2006b. Palynofacies and sequence stratigraphy of the Aptian/Albian of the Sergipe Basin, Brazil. Sediment Geol 192: 57-74.

Chagas RBA, MendonçA-Filho JG, Mendonça JO AND MENEZES TR. 2009. Caracterização palinofaciológica de uma sucessão sedimentar oligocênica da Formação Tremembé, Bacia de Taubaté. Rev Bras Paleontolog 12(3): 257-266.

CHENG H ET AL. 2009. Timing and structure of the $8.2 \mathrm{ky}$ event inferred from $\delta 180$ records of stalagmites from China, Oman and Brazil. Geology 37(11): 1007-1010.

Christopher RA. 1976. Morphology and taxonomic status of Pseudoschizaea Thiergart and Frantz ex R. Potonié emend. Micropaleontology 22(2): 143-150.

Cruz FW, Burns SJ, Karmann I, Sharp WD, Vuille M, Cardoso AO, Ferrari JA, Silva Dias PL and Viana $J_{R}$ O. 2005. Insolation-driven changes in atmospheric circulation over the past 116,000 years in subtropical Brazil. Nature 434: 63-66.

Del Papa C, García V and Quattrocchio M. 2002. Sedimentary facies and palynofacies assemblages in an Eocene perennial lake, Lumbrera Formation, northwest Argentina. J S Am Earth Sci, 15: 553-569.

DUARTE LC, HARTMANN LA, VASCONCELOS MAS, MEDEIROS JTN AND THEYE T. 2009. Epigenetic formation of amethyst-bearing geodes from Los Catalanes gemological district, Artigas, Uruguay, southern Paraná volcanic province. J Volcanol Geoth Res 184: 427-436.

ESTEVES FA. 2011. Gênese dos ecossistemas lacustres. In: Esteves FA (Ed), Fundamentos de Limnologia. Rio de Janeiro: Interciência, p. 83-112.

Fleitmann D, Burns SJ, Mudelsee M, NefF U, Kramers J, MANGINI A AND MATTER A. 2003, Holocene forcing of the Indian Monsoon recorded in a stalagmite from southern Oman. Science 300: 1737-1739.

FOLK RL AND WARD WC. 1957. Brazos river bar: a study of significante of grain size parameters. J Sediment Petrol 27: 3-26.

GIERLOWSKI-KoRDESCH EH AND KELTS KR. 2000. Lake Basins Through Space and Time. AAPG Studies in Geology 46, 638 p.

HARTMANN LA. 2008, Amethyst geodes formed from hot water in dinossaur times. Porto Alegre, Brazil, UFRGS, 57 p.

HARTMANN LA ET AL. 2012. Sequential opening and filling of cavities forming vesicles, amygdales and giant amethyst geodes in lavas from the southern Paraná volcanic province, Brazil and Uruguay. Int Geol Rev 54: 1-14.

Hartmann LA, Wildner W, Duarte LC, Duarte SK, Pertille J, Arena KR, Martins LC and Dias NL. 2010. Geochemical and scintillometric characterization and correlation of amethyst geode-bearing Paraná lavas from the Quaraí and Los Catalanes districts, Brazil and Uruguay. Geol Mag 147, 954-970. 
Haug G, Hughen K, Sigman DM, Peterson LC AND RÖHL U. 2001. Southward migration of the Intertropical Convergence Zone through the Holocene. Science 293: 1304-1308.

IEMINI JA, MENDONÇA-FILHO JG, GONÇALVES FTT AND MENEZES TR. 2007. Fácies orgânica da Formação La Luna, Bacia do Vale Superior de Magdalena, Colômbia: implicações para a geração de petróleo e caracterização paleoambiental. Anuário do Instituto de Geociências, Universidade Federal do Rio de Janeiro, Rio de Janeiro 30(2): 65-81.

JACOB J, DISNAR JR, BOUSSAFIR M, SIFEDDINE A, ALBUQUERQuE ALS AND TURCQ B. 2004. Major environmental changes recorded by lacustrine sedimentary organic matter since the Last Glacial Maximum under the tropics (Lagoa do Caçó, NE Brazil). Palaeogeogr Palaeoclimatol Palaeoecol 205: 183-197.

JACOB J, DISNAR JR, BOUSSAFIR M, SIFEDDINE A, Albuquerque AlS And TURCQ B. 2005. Pentacyclic triterpene methyl ethers in recent lacustrine sediments (Lagoa do Caçó, Brazil). Org Geochem 36, 449-461.

KÖPPEN W. 1948. Climatologia: con un estudio de los climas de la tierra. Fondo de Cultura Econômica. México. 479 p.

Ledru MP, Cordeiro RC, Dominguez JML, Martin L, Mourguiart P, SifEDdine A AND TURCQ B. 2001. Lateglacial cooling in Amazonia as inferred from pollen at Lagoa do Caçó, northern Brazil. Quaternary Res 55: 47-56.

Ledru MP, Mourguiart P, CeCCANTINI G, TurcQ B AND SIFEDDINE A. 2002. Tropical climates in the game of two hemispheres revealed by abrupt climatic change. Geology 30: $275-278$.

McCormac FG, Hogg AG, Blackwell PG, Buck CE, Higham TFG AND REIMER PJ. 2004. SHCal04 Southern Hemisphere Calibration, 0-11.0 cal kyr BP. Radiocarbon 46: 1087-1092.

MARKGRAF V. 1998. Past climates of South America. In: Hobbs JA, Lindsay JA and Bridgman HA (Eds), Climates of the Southern Continents: Present, Past and Future. Wiley, Chichester, p. 249-264.

MEDEANIC S AND SILVA MB. 2010. Indicative value of nonpollen palynomorphs (NPPs) and palynofacies for palaeoreconstructions: Holocene Peat, Brazil. Int J Coal Geol 84: 248-257.

MendonÇA-Filho JG. 1999. Aplicação de Estudos de Palinofácies e Fácies Orgânica em Rochas do Paleozóico Superior da Bacia do Paraná, Sul do Brasil. Ph.D. thesis. Universidade do Rio Grande do Sul.

Mendonça-Filho JG, CARVAlHo MA And Menezes TR. 2002. Palinofácies - técnicas e procedimentos de trabalho com formas fósseis e formas comparativas atuais. São Leopoldo: UNISINOS - Publicação Especial, p. 20-24.

MENDONÇA Filho JG, Chagas RBA, MENEZES TR, MENDONÇA JO, SILVA FS AND SABADINI-SANTOS E. 2010a. Organic facies of the Oligocene lacustrine system in the Cenozoic Taubaté basin, Southern Brazil. Int J Coal Geol 84: 166-178.

MENDONÇA-FilHo JG, MENEZES TR, MENDONÇA JO, OLIVEIRA AD, Carvalho MA, SANT'AnNa AJ AND Souza JT. 2010b. Palinofácies. In: Carvalho IS (Ed), Paleontologia, $3^{\text {a }}$ ed., Rio de Janeiro: Interciência 1: 289-323.
Menezes TR And MendonçA-Filho JG. 2004. Aplicação de Fácies Orgânica na Análise Paleoceanográfica do Talude Continental Superior Recente da Bacia de Campos, RJ, Brasil. Rev Bras Paleontolog 7(2): 177-188.

MendonçA-Filho JG, MenEZES TR AND MENdonçA JO. 2011. Chapter 5: Organic Composition (Palynofacies Analysis). In: Vasconcelos L, Flores D and Marques M (Eds), ICCP Training Program Commission I. ICCP Training Course on Dispersed Organic Matter, p. 33-81.

MeYer KEB, BÜCHI A, KarfunKel J, HofmanN M AND Hoppe A. 2010. Palinofácies e evolução quaternária do Ribeirão da Mata, Município de Vespasiano, MG, Brasil. Rev Bras Paleontolog 13(1): 41-48.

Meyer KEB, MendonçA-Filho JG, Ashraf AR, SouzA PA AND REICHHART K. 2005. Análises de Palinofácies em Sedimentos Holocênicos da Lagoa dos Quadros, Rio Grande do Sul, Brasil. Rev Bras Paleontolog 8(1): 57-72.

Meyer KEB, Souza PA, CWIK MR, Menezes TR AND BUChMANN FSC. 2006. Palinofácies e Processos Deposicionais em Sedimentos de Fundo da Lagoa dos Quadros, Planície Costeira do Rio Grande do sul, Brasil. Braz J Geol 36(4): 569-576.

Meyers PA AND LALlier-Verges E. 1999. Lacustrine sedimentary organic matter records of late quaternary paleoclimates. J Paleolimnol 21: 345-372.

Nö̈l H, Garbolino E, Brauer A, Lallier-Vergès E, De BEAULIEU JL AND DisnAR JR. 2001. Human impact and soil erosion during the last 5000 yrs as recorded in lacustrine sedimentary organic matter at Lac d'Annecy, the French Alps. J Paleolimnol 25: 229-244.

Pertille J, Hartmann LA, Duarte SK, Arena K, Rosa MLCC AND BARBOZA EG. 2013. Gossan characterization in the Quaraí and Los Catalanes amethyst geode districts (Brazil and Uruguay), Paraná volcanic province, using rock geochemistry and gamma-spectrometry. J Geochem Explor 124: 127-139.

REIMER PJ ET AL. 2004. IntCal04 Terrestrial radiocarbon age calibration, 0-26 cal kyr BP. Radiocarbon 46: 1029-1058.

ROSENSTENGEL LM AND HARTMANN LA. 2012. Geochemical stratigraphy of lavas and fault-block structures in the Ametista do Sul geode mining district, Paraná volcanic province, southern Brazil. Ore Geol Rev 48: 332-348.

SAlgado-LabouriaU ML, BARBERI M, VicENTINI KF AND PARIZZI MG. 1998. A dry climatic event during the late Quaternary of tropical Brazil. Rev Palaeobot Palyno 99: 115-129.

SALLUM AEM ET AL. 2012. Geochemical evidence of the 8.2 ka event and other Holocene environmental changes recorded in paleolagoon sediments, southeastern Brazil. Quaternary Res 77: 31-43.

SCHERER CMS. 2000, Eolian dunes of the Botucatu Formation (Cretaceous) in southernmost Brazil: Morphology and origin: Sediment Geol 137: 63-84.

SCOTT L. 1992. Environmental implications and origin of microscopic Pseudoschizaea Thiergart and Frantz Ex R. Potonie emend. in sediments: J Biogeogr 19: 349-354. 
Sebag D, Copard Y, Di-Giovanni C, Durand A, Laignel B, Ogier S ANd Lallier-Verges E. 2006. Palynofacies as useful tool to study origins and transfers of particulate organic matter in recent terrestrial environments: Synopsis and prospects. Earth-Sci Rev 79: 241-259.

SifEDDINE A ET AL. 2003. A 21000 cal years paleoclimatic record from Caçó Lake, northern Brazil: evidence from sedimentary and pollen analyses. Palaeogeogr Palaeoclimatol Palaeoecol189: 25-34.

SifEddine A, BertauX J, Mourguiart P, Martin L, Disnar JR, LAGGOUN-DÉFARGE F AND ARGOLLO J. 1998. Etude de la sédimentation lacustre d'un site de forêt d'altitude des Andes centrales (Bolivie). Implications paléoclimatiques. Bull Soc Geol Fr 169: 395-402.

Sifeddine A, Bertrand P, Foumier M, Martin L, Servant M, Soubies F, Suguio K And TurcQ B. 1994. La sedimentation organique lacustre en milieu tropical humide (Carajas, Amazonie oritntale, Br\&il): relation avec les changements climatiques au cows des 60,000 demitres annees. Bull Soc Geol Fr 165: 613- 621.

SifEddine A, Bertrand P, LALLIER-Verges E AND PATIENCE AJ. 1995. Organic sedimentation and its relationship with palaeoenvironmental changes over the last 30,000 years (Lac du Bouchet; Hte Loire, France). Comparison with other palaeoclimatic lacustrine examples). In: LallierVerges E, Tribovillard N and Bertrand P (Eds), Organic Mutter Accumulation: The Organic Cyclicities of the Kimmeridge Clay Formation (Yorkshire, G.B.) and the Recent Maar Sediments (Lac du Bouchet). Lec Notes Earth Sci 57: 157-168.

SIFEDDINE A, BERTRAND P, LALLIER-VERGÈs E AND PATIENCE AJ. 1996. Lacustrine organic fluxes and paleoclimatic variations during the last $15 \mathrm{ka}$ : Lac du Bouchet (Massif Central, France). Quaternary Sci Rev 15: 203-211.

SifEddine A, MARTIN L, TURCQ B, VolKMER-Ribeiro C, Soubiès F, Cordeiro RC AND Suguio K. 2001. Variations of the Amazonian rainforest environment: a sedimentological record covering 30,000 years. Palaeogeogr Palaeoclimatol Palaeoecol 168: 221-235.

SILVA YMP, MEYER KEB, PERÔNICO CAND CASTRO PTA. 2010. Palinofácies de uma seqüência sedimentar quaternária da Lagoa Preta, Parque Estadual do Rio Doce, MG, Brasil. Rev Bras Paleontolog 13(1): 49-56.

Stríkes NM, Cruz FW, Cheng H, Karmann I, Dwards RL, Vuille M, WANG X, PAula MS, Novello FS AND AUler AS. 2011. Abrupt variations in South American monsoon rainfall during the Holocene based on a speleothem record from central-eastern Brazil.Geology 39(11): 1075-1078.
Stuiver M, Reimer PJ, BArd E, Beck JW, Burr GS, Hughen KA, Kromer B, Mccormac G, VAn Der Plicht J And SPURK M. 1998. INTCAL98 Radiocarbon Age Calibration, 24000-0 cal BP. Radiocarbon 40(3): 1041-1083.

TALMA AS AND Vogel JC. 1993. A simplified approach to calibrating C14 dates. Radiocarbon 35: 317-322.

TenZer GE, Meyers PA AND KNOOP PA. 1997. Sources and distribution of organic and carbonate carbon in surface sediments of Pyramid Lake, Nevada. J Sediment Res 67: 884-890.

Thomas ER, WolfF EW, Mulvaney R, StefFensen JP, JOHNSEN SJ, ARRoWsmith C, White JWC, VAUGHN B AND PopP T. 2007. The $8.2 \mathrm{ka}$ event from Greenland ice cores. Quaternary Sci Rev 26 (1-2): 70-81.

Tturce B, Albuquerque ALS, Cordeiro RC, Sifeddine A, SimÕES-FILHO FFL, SOUZA AG, ABRÃo JJ, OLIVEIRA FBL, Silva AO AND CAPitÂNeO J. 2002. Accumulation of organic carbono in five Brazilian lakes during the Holocene. Sediment Geol 148: 319-342.

TYSON RV. 1995. Sedimentary Organic Matter: organic facies and palynofacies. London: Chapman \& Hall, 615 p.

TYSON RV. 2001. Sedimentation rate, dilution, preservation and total organic carbon: some results of a modeling study. Org Geochem 32: 333-339.

U.S.EPA - United States EnVIRONMENTAL Protection AGENCY. 2002. Methods for the determination of Total Organic Carbon (TOC) in soils and sediments. Ecological Risk Assessment Support Center. NCEA-C-1282. Office of Research and Development, Las Vegas.

VALENTIN JL. 2000. Ecologia numérica. Interciência, Rio de Janeiro, 62 p.

VAN GELL B. 1978. A palaeoecolgical study of Holocene peat bog sections in Germany and the Netherlands, based on one analysis of pollen and macro and microscopic remais of fungi, algae, cormophytes and animals. Rev Palaeobot Palyno 25: 1-120.

VAN GeEL B AND VAN DER HAMmEn T. 1978. Zignemataceae in Quaternary Colombian sediments. Rev Palaeobot Palyno 25(5): 377-392.

WANG Y, Cheng H, Edwards RL, He Y, Kong X, AN Z, Wu J, Kelly MJ, DyKOSK CA AND Li X. 2005. The Holocene Asian Monsoon: Links to solar changes and North Atlantic climate. Science 308: 854-857.

WILliams JW, BLOIS JL AND SHUMAN BN. 2011. Extrinsic and intrinsic forcing of abrupt ecological change: case studies from the late Quaternary. J Ecol 99: 664-677. 